\title{
A Critical View of the Photoinitiated Degradation of Herbicides
}

\author{
Šárka Klementová \\ Faculty of Science University of South Bohemia \\ Czech Republic
}

\section{Introduction}

The application of herbicides to agricultural soil is a well established and effective practice to control weed growth. Another areas of herbicide application are roads and railways where herbicides are used to mantain the quality of the track and a safe working environment for railway personnel (Torstenson, 2001). Some of total herbicides are used in urban areas, or as algicides in paints and coatings (Lindner et al.,2000). Among the wide range of herbicides available, phenyl-urea and triazine derivatives represent a prominent group, the variety and use of which having increased markedly during the past decades. Many of the compounds in both families are biorecalcitrant, i.e. their microbiological degradation is slow or totally ineffective, they therefore persist in the environment for many weeks or even months after application.

The partial water solubility of triazines and phenylurea herbicides results in their leaching or washing into surface and ground waters from the place of application.

For many important classes of pesticides including phenylurea and triazine herbicides, photoinitiated transformation may be the only relevant elimination process in surface waters. In waste-waters, advanced photochemical oxidation processes (EPA Handbook, 1998) using oxidative agents/UV combination have been under study.

\section{Photoinitiated reactions}

Each reaction started by an absorption of radiation may be classified as a photochemical or photoinitiated reaction. According to the mechanism of the photoinitiated reaction, photolytic, photosensitized and photocatalytic reactions can be distinguished.

A photolytic reaction is usually understood as a reaction in which the quantum of radiation absorbed has enough energy to cause the breaking of a covalent bond in the substrate compound. Usually highly energetic UV radiation (less than $250 \mathrm{~nm}$ ) is necessary for this purpose. These reactions cannot proceed on the Earth's surface since solar radiation reaching the Earth's surface contains wavelengths greater than $290 \mathrm{~nm}$.

A photosensitized reaction needs a sensitizer molecule. This is a molecule that is able to absorb radiation and to transfer the absorbed excitation energy onto another molecule. The 
energy can be transferred either onto an organic molecule, substrate (e.g. herbicide molecule), or onto an oxygen molecule as shown in Eqs. 1 - 5.

$$
\begin{aligned}
& { }^{1} \text { Sens }+\mathrm{h} v \rightarrow{ }^{1} \text { Sens }{ }^{*} \\
& { }^{1} \text { Sens }{ }^{*}+{ }^{1} \text { Substrate } \rightarrow{ }^{1} \text { Substrate }{ }^{*}+{ }^{1} \text { Sens } \rightarrow \text { Product }+{ }^{1} \text { Sens } \\
& { }^{1} \text { Sens* } \rightarrow \text { through ISC } \rightarrow{ }^{3} \text { Sens* } \\
& { }^{3} \text { Sens }{ }^{*}+{ }^{3} \mathrm{O}_{2} \rightarrow{ }^{1} \mathrm{O}_{2} \\
& { }^{1} \mathrm{O}_{2}+1 \text { Substrate } \rightarrow \text { Oxidized product }
\end{aligned}
$$

Eq.1 represents excitation of the sensitizer from the ground state (which is always a singlet state, i.e. all electrons in the molecule are paired) to the first excited singlet state. Eq. 2 represents energy transfer onto the substrate and its subsequent reaction into a product. Eq. 3 represents the conversion of the sensitizer from the first excited singlet state (all electrons are paired in the molecule in a singlet state) into the first triplet state (where two electrons are unpaired) through so called intersystem crossing (ISC). The sensitizer in the triplet state is able to react with molecular oxygen dissolved in the reaction mixture (Eq.4) because the ground state of molecular oxygen with its two unpaired electrons is a triplet state. If this ISC process did not occur, the reaction would not proceed since a reaction between a singlet and a triplet state molecule is spin-forbidden. The reaction results in the formation of a powerful oxidative species, singlet oxygen that oxidizes organic substrate molecules (Eq. 5).

Photocatalysis may occur as a homogeneous process or as a heterogeneous process. In homogeneous photocatalytic reactions light produces a catalytically active form of a catalyst. E. g. ferric ions may be reduced photochemically in the presence of an electron donor to ferrous ions that exhibit much higher catalytic activity. The subsequent catalytic reaction of a substrate is a 'dark' reaction, i.e. not photochemical, since the reaction does not need light. Heterogeneous photocatalysis includes photochemical reactions on semiconductors. It proceeds via the formation of an electron-hole pairs under irradiation. These holes and electrons react with the solvent (water) and dissolved oxygen to produce an oxidative species, mainly $\mathrm{OH}$ radicals (Eqs. 6 - 11).

$$
\begin{gathered}
\mathrm{h}^{+}+\mathrm{H}_{2} \mathrm{O} \rightarrow \mathrm{HO}^{*}+\mathrm{H}^{+} \\
\mathrm{h}^{+}+\mathrm{OH}^{-} \rightarrow \mathrm{HO} \cdot \\
\mathrm{O}_{2}+\mathrm{e}^{-} \rightarrow \mathrm{O}_{2}^{*-} \\
\mathrm{O}^{--}+\mathrm{H}^{+} \rightarrow \mathrm{HO}_{2}^{*} \\
2 \mathrm{HO}_{2}^{*} \rightarrow \mathrm{H}_{2} \mathrm{O}_{2}+\mathrm{O}_{2} \\
\mathrm{H}_{2} \mathrm{O}_{2}+\mathrm{O}_{2}^{*-} \rightarrow \mathrm{HO}^{*}+\mathrm{O}_{2}+\mathrm{OH}^{-}
\end{gathered}
$$




\section{Characterisation of s-triazine and phenylurea herbicides}

S-triazine herbicides contain an aromatic ring with three $\mathrm{N}$ heteroatoms. The formula of a triazine herbicide, atrazine, is shown in Fig. 1., the formula of a phenylurea herbicide, chlorotoluron, in Fig. 2.

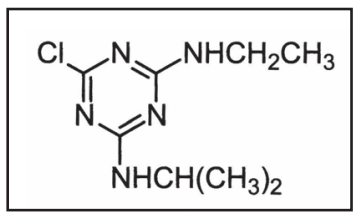

Fig. 1. The structural formula of a triazine herbicide, atrazine.

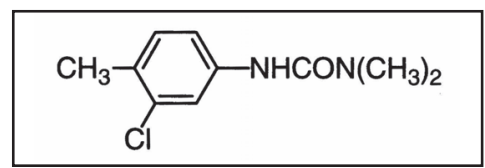

Fig. 2. The structural formula of a phenylurea herbicide, chlorotoluron .

The triazine herbicides were introduced in the 1950s (Gysin \& Knüsli, 1957, Gast et al., 1956, both in Tomlin, 2003), phenylurea pesticides a decade later (L'Hermite et al., 1969, in Tomlin 2003).

The solubilities of these herbicides in water are in milligrams or at most tens of milligrams per liter as shown for three trazine and one phenylurea herbicide in Table 1. Table 1 also summarizes the $\mathrm{DT}_{50}$ values for the selected herbicides. $\mathrm{DT}_{50}$ signifies $50 \%$ dissipation time, i.e. the amount of time required for $50 \%$ of the initial pesticide concentration to dissipate. Unlike half-life dissipation time does not assume a specific degradation model.

\begin{tabular}{|l|l|l|}
\hline Herbicide & solubility $(\mathrm{mg} / \mathrm{l})$ & $\mathrm{DT}_{50}$ (days) \\
\hline Atrazine & $33\left(22^{\circ} \mathrm{C}\right)$ & $\begin{array}{l}\text { field: } 16-77, \text { median } 41 \\
\text { natural waters: } 10-105 \\
\text { groundwaters: } 105->200\end{array}$ \\
\hline Propazine & $5.0\left(20^{\circ} \mathrm{C}\right.$ & soil: $80-100$ \\
\hline Simazine & $6.2\left(20^{\circ} \mathrm{C}\right)$ & soil: $27-102$ \\
\hline chlorotoluron & $74\left(25^{\circ} \mathrm{C}\right)$ & $\begin{array}{l}\text { soil: } 30-40 \\
\text { water: }>200\end{array}$ \\
\hline
\end{tabular}

Table 1. Solubilities and $\mathrm{DT}_{50}$ values of selected triazine and phenylurea herbicides as given in Tomlin (2003).

All these herbicides are photosynthetic electron transport inhibitors at the photosystem II receptor site. They are all also systemic herbicides. Systemic herbicides (in comparison with contact herbicides) are translocated through the plant, either from foliar application down to the roots or from soil application up to the leaves. They are capable of controlling perennial plants and may be slower in action but ultimitaly more effective than contact herbicides. 


\section{Biodegradation of selected triazine and phenylurea herbicides}

\subsection{Biodegradation of triazines}

In spite of the fact that triazine and phenylurea herbicides persist in the natural environment for a long time and do not undergo biodegradation easily there are some higher plants and microorganisms capable of metabolizing these compounds.

In tolerant plants triazines as well as phenylurea herbicides are readily metabolized. Plant metabolites include the hydroxy- and dealkylated derivatives of parental compounds. Atrazine (6-chloro-N22-ethyl-N4-isopropyl-1,3,5-triazine-2,4-diamine) is metabolized in tolerant plants to hydroxyatrazine and amino acid conjugates, with further decompositon of hydoxyatrazine by degradation of the side-chains. The resulting amino acids on the ring are hydrolyzed and mineralized (i.e. degraded to $\mathrm{CO}_{2}$ ). In sensitive plants, unaltered atrazine accumulates, leading to chlorosis (a condition in which leaves produce insufficiant amounts of chlorophylls) and death. The similar degradation or action pathways apply for propazine (6-chloro- $\mathrm{N}^{2}, \mathrm{~N}^{4}$-di-isopropyl-1,3,5-triazine-2,4-diamine) and simazine (6-chloro- $\mathrm{N}^{2}, \mathrm{~N}^{4}$ diethyl-1,3,5-triazine-2,4-diamine). With chlorotoluron (3-(3-chloro-p-tolyl)1,1dimethylurea), metabolites found in winter wheat include 3-chloro-p-toluidine,3- (3-chloro4-methylphenyl)-1-methylurea and 1-(3-chloro-4-methylphenyl)urea (Tomlin, 2003).

Behki and Khan studied agricultural soils to which atrazine was applied for a long time. They isolated three bacteria strains (Pseudomonas family) capable of utilizing atrazine as the sole source of carbon (Behki \& Khan, 1986). Those bacteria use the side-chain carbon, thus $\mathrm{N}$-dealkylation resulting in desisopropylatrazine and desethylatrazine was observed. Two bacterial strains were able to cause the splitting of chlorine from atrazine as well as from the dealkylated metabolites. The same authors proved the capacity to degrade atrazine, propazine, and simazine in the bacteria of Rhodococcus species (Behki \& Khan, 1994), the degradation rates being however lower than in Pseudomonas bacteria.

Not only bacteria but also other organisms such as soil fungal communities have been found to be able to attack and degrade triazines (Kodama et al., 2001).

A Pseudomonas bacterial strain was used to degrade atrazine by Wenk (Wenk et al., 1998). The rate of atrazine disappearance was shown to depend on the water content of the soil and on the number of inoculated bacteria; the time necessary for atrazine removal differed ranging from 1 to 25 days. A partial mineralisation of atrazine into $\mathrm{CO}_{2}$ was also observed.

Such results are in agreement with the findings of Crawford and his coworkers (Crawford et al., 2000), who concluded that the biodegradation rate is affected by the properties of soils and sediments, by agricultural cultivation practices and by the history of triazine application onto the particular soil.

Two genes responsible for s-triazine degradation have been found in four bacterial phyla (Jason Krutz et al., 2010).

\subsection{Biodegradation of phenylurea chlorotoluron}

Biotransformation of phenylurea herbicides by soil microorganisms (bacterial and fungi) has been reported by several authors (Badawi et al., 2009; Khadrani et al., 1999; Sørensen et al., 2003; Tixier et al., 2002). Bacteria degrade phenylurea herbicides by successive N- 
dealkylation to substituted aniline products. Fungal pathways result in successive dealkylated metabolites as well as aniline derivatives, but Badawi (Badawi et al., 2009) reported the detection of a new major metabolite which (according to thin layer chromatography and nuclear magnetic resonance spectrometry) is a non-aromatic diol.

Biodegradation by some bacterial and fungal strains leads to the formation of very toxic substituted anilines which have even higher levels of $\mathrm{LD}_{50}$ - the dose required to kill half the members of a tested population after a specified test duration time (Tixier et al., 2000a; Tixier et al, 2009). The same applies to products of photochemical degradation (Tixier et al., 2000b).

\section{Photochemical degradation of triazine and phenylurea herbicides}

\subsection{Possible photoinitiated pathways for herbicide degradation}

An organic substrate may undergo the following photoinitiated reactions under natural sunlight or artificial source irradiation:

- direct sunlight photodegradation;

- homogeneous photocatalytic degradation in the presence of dissolved metal ions;

- heterogeneous photocatalytic degradation on particulate metal compounds in natural waters;

- $\quad$ heterogeneous photocatalytic degradation on semiconductors;

- $\quad$ photosensitized reaction - reaction in the presence of sensitizers;

- photolytic degradation by short-wavelength irradiation.

For a pollutant the processes given above are schematically visualized in Fig. 3.

\subsection{Direct sunlight photodegradation}

Direct sunlight photodegradation can proceed with substrates that are able to absorb the solar action spectrum. Solar radiation reaching the Earth's surface has wavelengths ranging from about $300 \mathrm{~nm}$ upwards. Triazine and phenylurea compounds, which absorb at range well below $300 \mathrm{~nm}$ (absorption maxima at $220-235 \mathrm{~nm}$ ) cannot therefore undergo direct sunlight photodegradation.

\subsection{Homogeneous photocatalytic degradation in the presence of dissolved metal ions}

Homogeneous photocatalytic reactions of triazine herbicides in the presence of dissolved metal ions were studied for ferric, copper, and manganese ions (Klementova \& Hamsova, 2000). Cupric and manganese (II) ions exhibited only small activities, and only in high concentrations. Table 2 shows the results for atrazine degradation in aqueous solutions under irradiation at a range of wavelengths from 300 to $350 \mathrm{~nm}$. When no metal ions are added, no reaction occurs.

In the case of atrazine the addition of $\mathrm{Cu}$ (II) or $\mathrm{Mn}$ (II) ions results in conversion below $15 \%$ or less. Ferric ions in comparable concentration cause the conversion of practically all the atrazine in 90 minutes of irradiation. The degradation of atrazine was shown to be strongly dependent on the ferric ion concentration (Fig. 4). Simazine and propazine did not show such a strong dependence on the added ferric ions. 


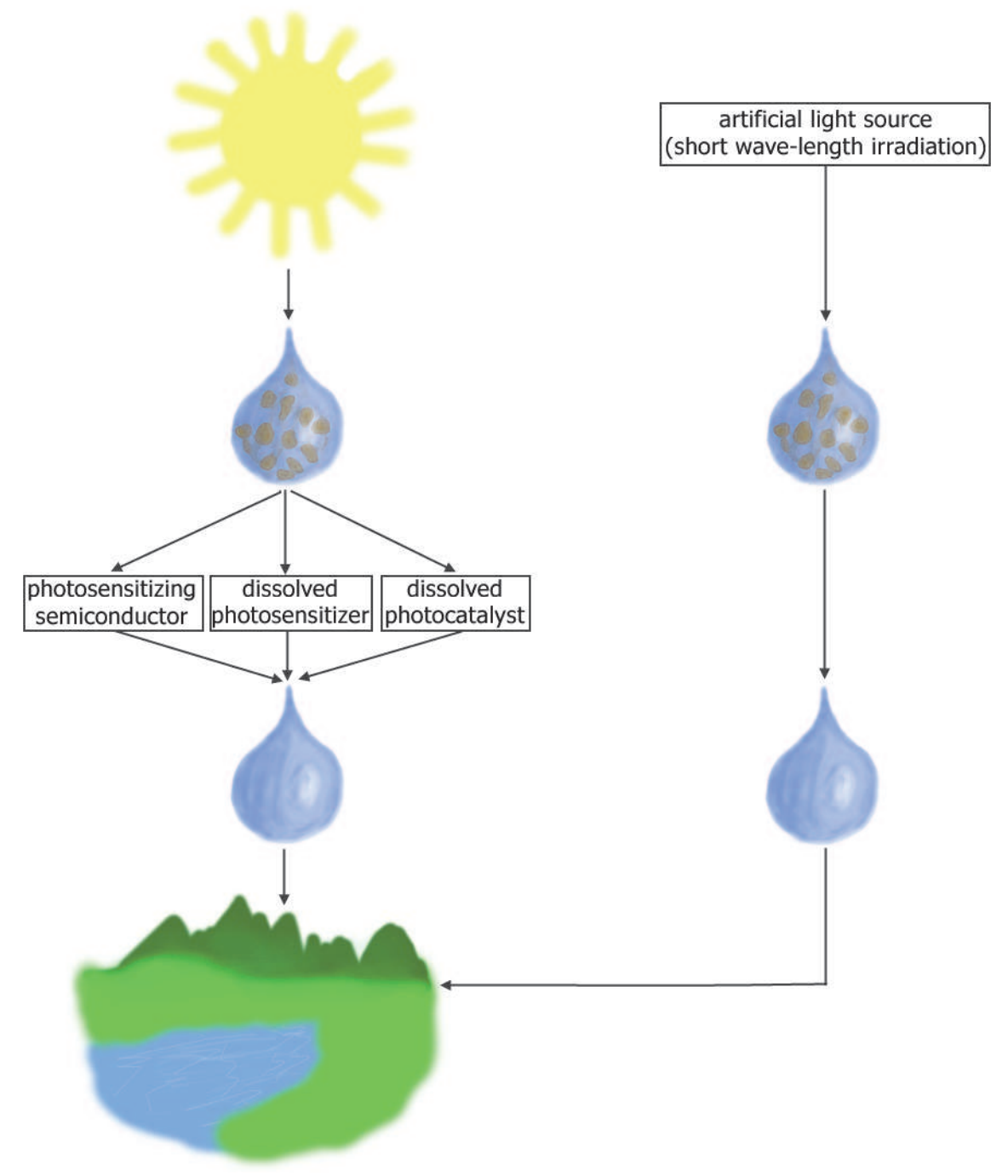

Fig. 3. Scheme of possible degradation pathways of a pollutant non-absorbing solar radiation.

In order to prove the photocatalytic mechanism of the degradation in the triazine solutions, formation of $\mathrm{Fe}^{2+}$ ions was measured in the reaction system. The results are set out in Fig. 5 . 


\begin{tabular}{|c|c|c|c|c|c|c|c|}
\hline & \multicolumn{7}{|c|}{$\begin{array}{c}\text { atrazine consumption } \\
(\% \text { of initial concentration })\end{array}$} \\
\hline $\begin{array}{c}\text { time of } \\
\text { irrad. } \\
\text { (minutes) }\end{array}$ & $\begin{array}{c}\text { no } \\
\text { added } \\
\text { metal } \\
\text { ions }\end{array}$ & $\begin{array}{c}\mathrm{Cu}(\mathrm{II}) \\
3.3^{*} 10^{-4} \\
\mathrm{~mol} / 1\end{array}$ & $\begin{array}{c}\mathrm{Cu}(\mathrm{II}) \\
1.0^{*} 10^{-3} \\
\mathrm{~mol} / 1\end{array}$ & $\begin{array}{c}\mathrm{Mn}(\mathrm{II}) \\
1.6^{*} 10^{-4} \\
\mathrm{~mol} / 1\end{array}$ & $\begin{array}{c}\mathrm{Mn}(\mathrm{II}) \\
1.0^{*} 10^{-3} \\
\mathrm{~mol} / 1\end{array}$ & $\begin{array}{c}\mathrm{Fe}(\mathrm{III}) \\
1.0^{*} 10^{-4} \\
\mathrm{~mol} / 1\end{array}$ & $\begin{array}{c}\mathrm{Fe}(\mathrm{III}) \\
3.3^{*} 10^{-4} \\
\mathrm{~mol} / 1\end{array}$ \\
\hline 0 & 0 & 0 & 0 & 0 & 0 & 0 & 0 \\
\hline 30 & 0 & 6 & 8 & 1 & 7 & 30 & 97 \\
\hline 60 & 0 & 8 & 12 & 4 & 8 & 64 & 98 \\
\hline 90 & 0 & 14 & 15 & 6 & 9 & 98 & 99 \\
\hline
\end{tabular}

Table 2. Degradation of atrazine in photoinitiated reaction in air saturated aqueous solution in the presence of metal ions. Initial concentration of atrazine $5.0^{*} 10^{-5} \mathrm{~mol} / 1$. Irradiation:

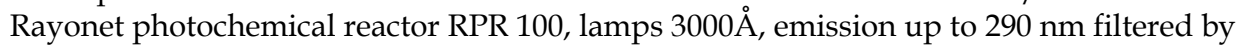
optical glass. (From Klementová \& Hamsová, 2000.)

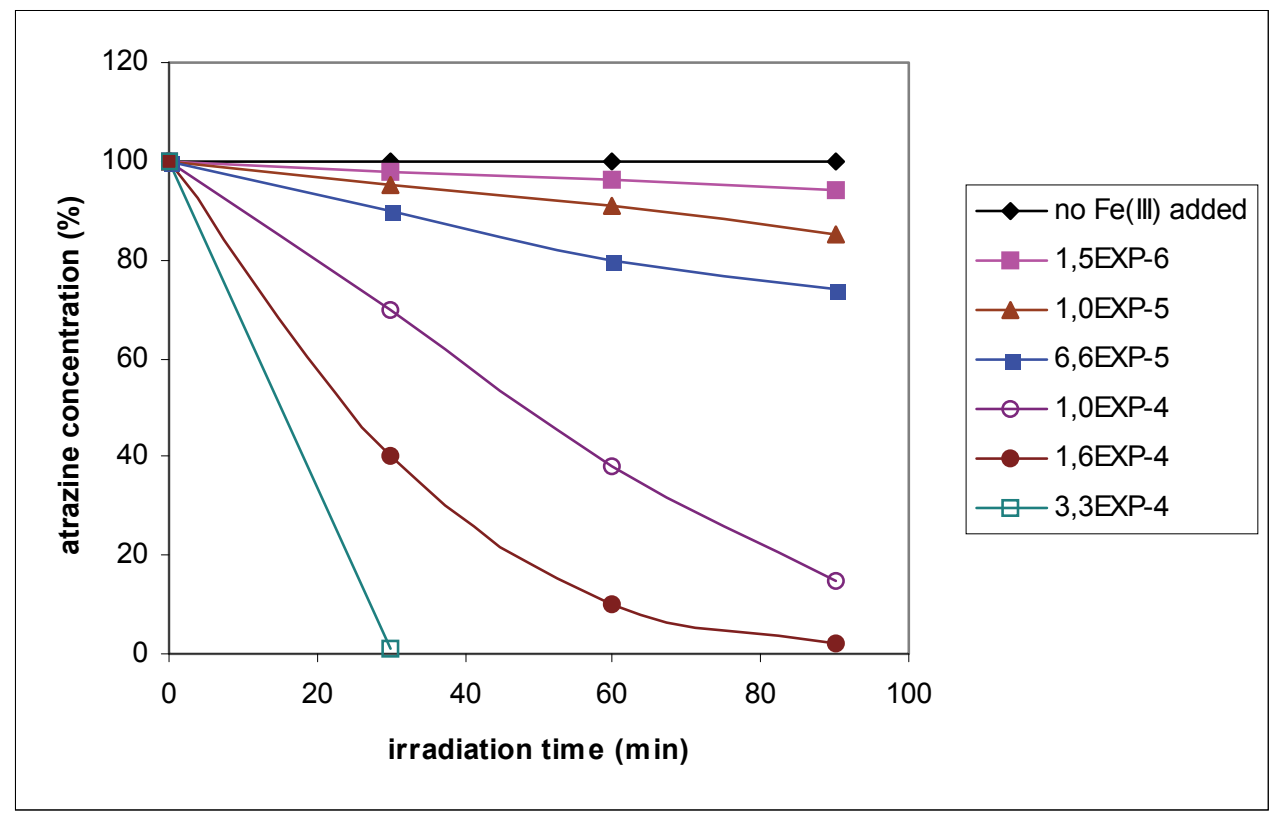

Fig. 4. Effect of ferric ions concentration on atrazine photochemical degradation (conditions of irradiation see Tab.2). Initial concentration of atrazine $5.0^{*} 10^{-5} \mathrm{~mol} / 1$. (From Klementová \& Hamsová, 2000).

The photoreduction of ferric to ferrous ions occurs quickly under the irradiation of all three triazines, atrazine, propazine and simazine, though the reaction mixtures were saturated by the air. In the steady state, about $23 \%$ of added ferric ions are present in the reduced form in the reaction mixture of atrazine, about $70 \%$ in the reaction mixture of propazine, and nearly $90 \%$ in the reaction mixture of simazine. 


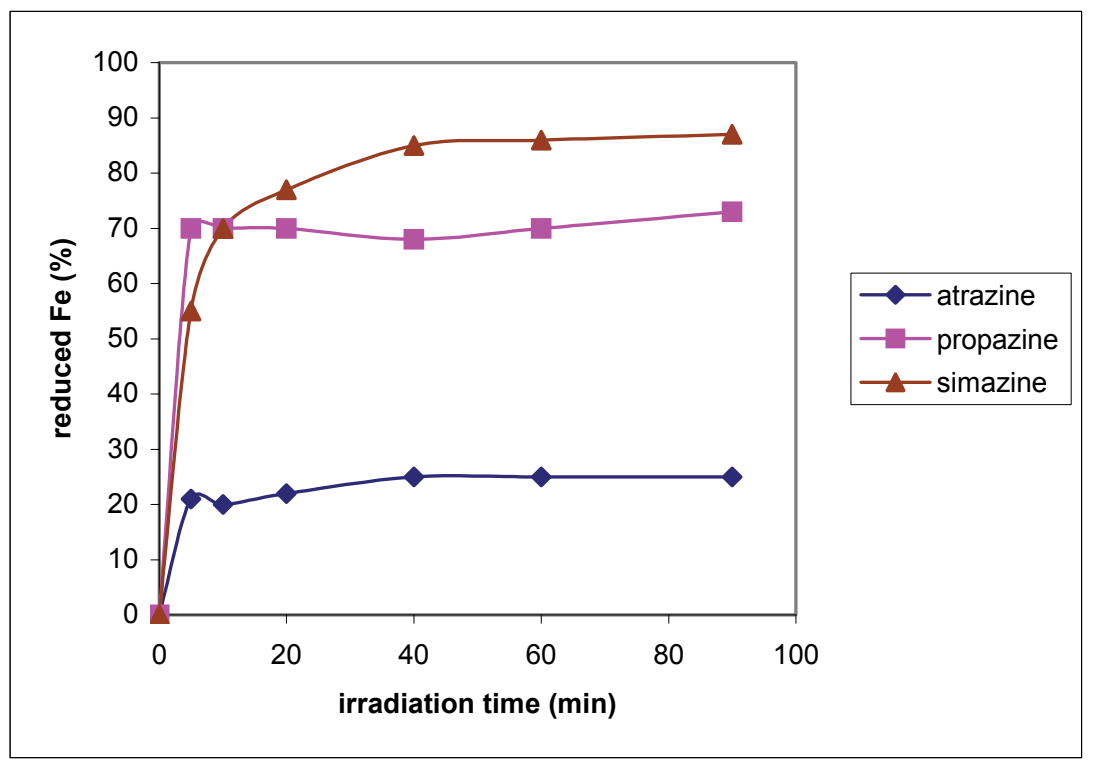

Fig. 5. Photochemical reduction of Fe(III) in the reaction systems with atrazine, propazine and simazine, resp., in the air saturated reaction mixtures. Concentration of substrates $5.0^{*} 10^{-5} \mathrm{~mol} / \mathrm{l}$, concentration of initial $\mathrm{Fe}^{3+}$ ions $1.0^{*} 10^{-4} \mathrm{~mol} / \mathrm{l}$. Conditions of irradiation - see Table 2. (From Klementová \& Hamsová, 2000).

Homogeneous photocatalytic reactions in the presence of ferric ions may provide a possible pathway for the photochemical degradation of atrazine in water bodies; the problem being that the iron content in natural surface waters is about $1^{*} 10^{-5} \mathrm{~mol} / \mathrm{l}$, a relatively ineffective concentration for atrazine degradation. Other triazine derivatives, propazine and simazine, seem not to be affected by homogeneous photocatalytic degradation in the presence of the ions that are most abundant in natural waters (iron and manganese).

\subsection{Heterogeneous photocatalytic degradation}

There are no data on the heterogeneous photocatalytic degradation of herbicides with particulate matter in natural waters. Ample studies deal on the other hand with heterogeneous photochemical degradation in relation to semiconductors especially in the context of decontamination option for drinking water and in waste-water treatment.

Semiconductor photocatalysis uses solid catalytic systems where five discrete stages associated with conventional heterogeneous catalysis can be distinguished:

a. transfer of liquid or gaseous phase reactant to the catalytic surface by the diffusion;

b. adsorption of the reactant on the catalyst surface;

c. reaction of the adsorbed molecules;

d. desorption of products;

e. removal of products from the interface region by the diffusion. 
The photocatalytic reaction occurs in the stage where the reactants are absorbed on the catalyst surface, the activation of the reaction being photonic activation. The semiconductor is activated by irradiation from a light source of appropriate wavelength depending on the band gap energy of the semiconductor. The activation generates a pair of charge carriers, a hole, $h^{+}$, and an electron, $e$; the charge carriers generated photochemically can react with molecules on the surface of the semiconductor (Eqs. 6-11 and Fig. 6).

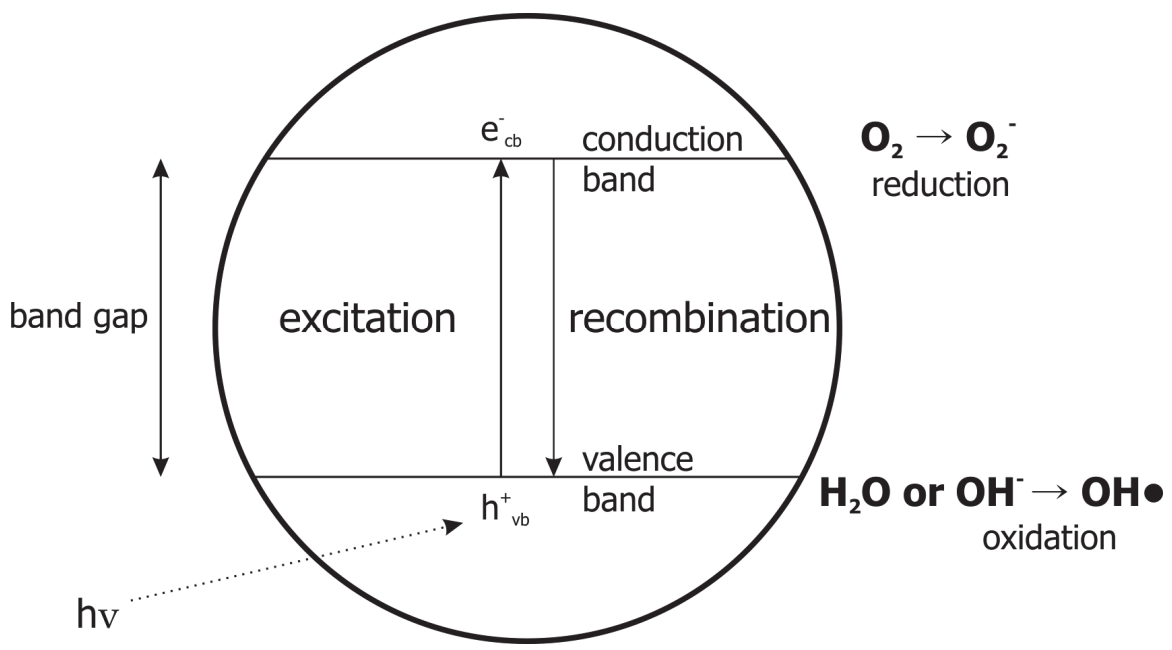

Fig. 6. Scheme of oxidative species production on semiconductors under irradiation.

Various metal oxides, e.g. $\mathrm{TiO}_{2}$ (Hashimoto et al, 2005; Héquet et al., 2001; Konstantinou et al., 2001a; Linsebigler et al., 1995; Pelizzetti et al, 1990; Penuela\& Barceló, 2000) ZnO (Byrappa et al., 2006), $\mathrm{CeO}_{2}$ (Yongging $\mathrm{Zha}$ et al., 2007), $\mathrm{ZrO}_{2}$ (Bota et al., 1999), $\mathrm{WO}_{3}$ (Guo et al., 2007) and many other composites of semiconductors or doped semiconductors have been used as catalysts in semiconductor photocatalytic reactions (e.g. Dunliang et al. , 2009).

$\mathrm{TiO}_{2}$ - the most widely used semiconductor in contaminant photocatalysis - occurs in three distinct polymorphs: anatase, rutile and brookite. Of these three forms only anatase is functional as a photocatalyst. Anatase is a typical n-type semiconductor with a band gap of about $3.2 \mathrm{eV}$. Photons with a wavelength shorter then $385 \mathrm{~nm}$ have enough energy to excite electrons from the valence band to the conduction band of this material. Since the 1970s, anatase has been a popular choice as semiconductor photocatalyst in research efforts because it is non-toxic and mechanically stable, has high photo-activity and low cost, and exhibits a reasonable overlap with the ultra-violet portion of the solar spectrum which makes it attractive for solar applications. Up to now a multitude of compounds have been investigated as target pollutants in photocatalytic oxidation studies on $\mathrm{TiO}_{2}$. The studies have been performed at bench scale using small reactors operating as batch or flow reactor systems. Besides pollutant degradation successful tests for the treatment of bacteria, viruses, fungi, and tumor cells have been reported. Construction materials coated with $\mathrm{TiO}_{2}$ exhibit self-cleaning properties (Devilliers, 2006).

Triazine herbicides photocatalytic degradation on $\mathrm{TiO}_{2}$ has been studied by several authors, e.g. Héquet et al., 2001; Konstantinou et al., 2001;Pelizzetti et al., 1990; Penueala \& Barceló, 
2000), in some cases with the addition of oxidative species such as hydrogen peroxide or photo-Fenton system, $\mathrm{H}_{2} \mathrm{O}_{2} / \mathrm{Fe}(\mathrm{III})$, providing hydroxyl radicals. Atrazine was found to be degraded to desethylatrazine and desisopropylatrazine, i. e. the same compounds that are metabolites of biodegradation. These metabolites are not easily further degraded in the photocatalytic process on $\mathrm{TiO}_{2}$.

In our group (Klementová, 2011), we compared the degradation of atrazine in the homogeneous photocatalytic reaction in the presence of $\mathrm{Fe}$ (III) and the photocatalytic degradation on $\mathrm{TiO}_{2}$ (batch experiment, glass coated with $\mathrm{TiO}_{2}$, irradiation by Philips TLD $15 \mathrm{~W} 08$ lamps). The reaction constant of the heterogeneous photocatalytic reaction $(0.018$ $\mathrm{min}^{-1}$ ) was comparable with the reaction constant in reaction mixtures with higher concentrations of ferric ions $\left(0.021 \mathrm{~min}^{-1}\right.$ for Fe(III) concentration $\left.1.4^{\star} 10^{-4} \mathrm{~mol} / \mathrm{l}\right)$.

The degradation of phenylurea herbicides on $\mathrm{TiO}_{2}$ has been studied e.g. by Amorisco et al.(2006), Haque et al. (2006) and Lhomme et al. (2005). The results of such studies show the importance of operational conditions (adsorption capacity, initial concentrations chlorotoluron, $\mathrm{TiO}_{2}$ forms - coated or in suspension (Lhomme et al., 2005). The pathway of chlorotoluron degradation contained a substitution of chloride ion by the hydroxyl group on the aromatic ring, the demethylation of $\mathrm{N}$ group on the side chain, and in some cases a breaking down of the aromatic ring was observed.

Heterogeneous photocatalysis may represent a feasible pathway for the degradation of herbicides in waste-water treatment or even drinking water treatment, especially under conditions where the aromatic ring structure is broken down.

\subsection{Photosensitized reactions}

Photosensitized reactions may proceed in natural waters in the presence of natural sensitizers such as humic substances. Humic substances originate from the decay of plant and animal biomass and humification reactions in the decaying material. The molecules of humic substances are of variable structure and size (molecular weight ranging from several hundreds to several hundreds of thousands). Humic substances are classified into three operational classes:

- $\quad$ humic acids, which are non-soluble under low $\mathrm{pH}$ values,

- fulvic acids, which are soluble at all $\mathrm{pH}$ values,

- humins, which is the insoluble fraction.

Humic acids and fulvic acids have an acidic character due to their substential content of carboxylic and phenolic functional groups (Schnitzer \& Khan, 1972); Dojlido \& Best, 1993). The basic structural features of humic and fulvic acids are shown in Fig. 7.

Humic and fulvic acids have featureless absorption spectra with increasing absorption from the short-wavelengths of visible light through the ultraviolet radiation range.

Photosensitizing properties resulting in the production of singlet oxygen molecules $\left({ }^{1} \mathrm{O}_{2}\right)$, superoxide anions $\left(\mathrm{O}_{2}^{-}\right)$, hydroxyl radicals $\left(\mathrm{HO}^{*}\right)$, peroxyradicals $\left.(\mathrm{ROO})^{*}\right)$, and hydrated electrons $\left(\mathrm{e}_{\mathrm{aq}}^{-}\right)$have been well established (Cooper et al., 1989; Hoigné et al., 1989; Mill T., 1989; Simmons \& Zepp, 1986). 


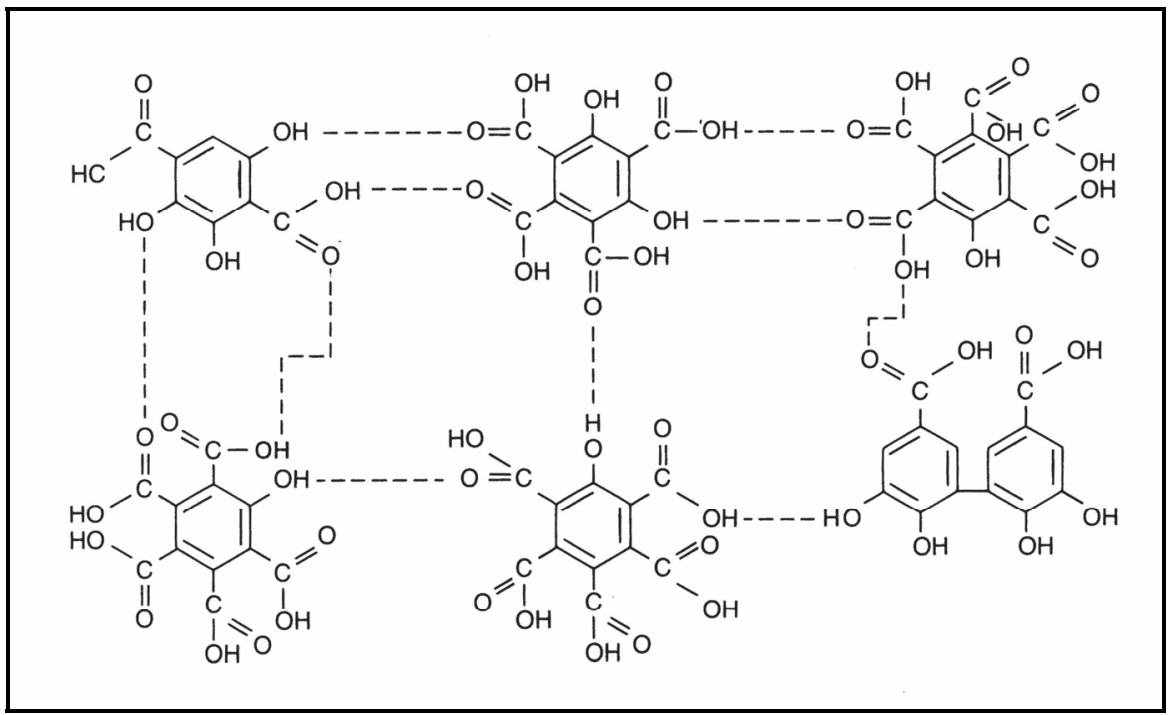

Fig. 7. Structure of fulvic acids. (From Dojlido \& Best, 1993).

The photosensitized degradation of triazine and phenylurea herbicide in the presence of humic substances has been studied by several authors, e.g. Amine-Khodja et al. (2006); Comber (1999); Gerecke et al. (2001); Klementova \& Piskova (2005); Konstantinou et al. (2001b), Minero et al. (1992) and Schmitt et al. (1995). The results suggest that there is no unambiguous answer about the influence of humic substances. Some authors report better degradation of the substrates, other report decrease in reaction rates in the presence of humic substances. The explanation probably lies in the combination of absorption characteristics of humic samples, their concentrations and the light sources used in the studies. In concentrated humic waters, inner filtration (i. e. the absorption of a significant part of the radiation energy by the photosensitively inactive parts of humic molecules) may play an important role and cause a decrease in the reaction rate of degradation. The heterogeneous chemical character of humic fractions may also be responsible for the variable photosensitizing activities of individual humic samples.

Two groups of artificial sensitizers which provide defined oxidative species were studied in our group for triazine and triazine metabolite degradation: phthalocyanines, i.e. photosensitizers providing singlet oxygen, and anthraquinonesulfonate causing formation of superoxide anions (Klementová \& Hamsová, 2000). To our surprise phthalocyanines (aluminium-chloro-phthalocynanine-disulfonate and zinc-phthalocyanine-trisulfonate) showed no observable effect. Anthraquinonesulfonate presence in the aqueous solutions of triazine herbicides (atrazine, propazine, simazine) and the two of atrazine metabolites (desethylatrazine and desisopropylatrazine) resulted in a relatively swift degradation (Fig. 8). Anthraquinonesulfonate was repeatedly added to the reaction mixtures since its molecules are degraded by UV light. This result suggests that triazine herbicides are readily degradable by superoxide species. Nevertheless, the aromatic ring is not broken down so the decomposition is incomplete as it is in other sensitized and catalyzed reactions. 


\subsection{Photolytic degradation by short-wavelength radiation}

Direct photolytic degradation is a decomposition that follows the absorption of a photon (and therefore a rearrangement in the electron density distribution of the molecule in the excited state). The reaction includes only one reactant, i.e. the molecule that undergoes photolysis. The products of a photolytic splitting may undergo another photolytic decompositon if the radiation is of a suitable wavelength. The reaction follows the first order kinetics scheme (Eq. 12).

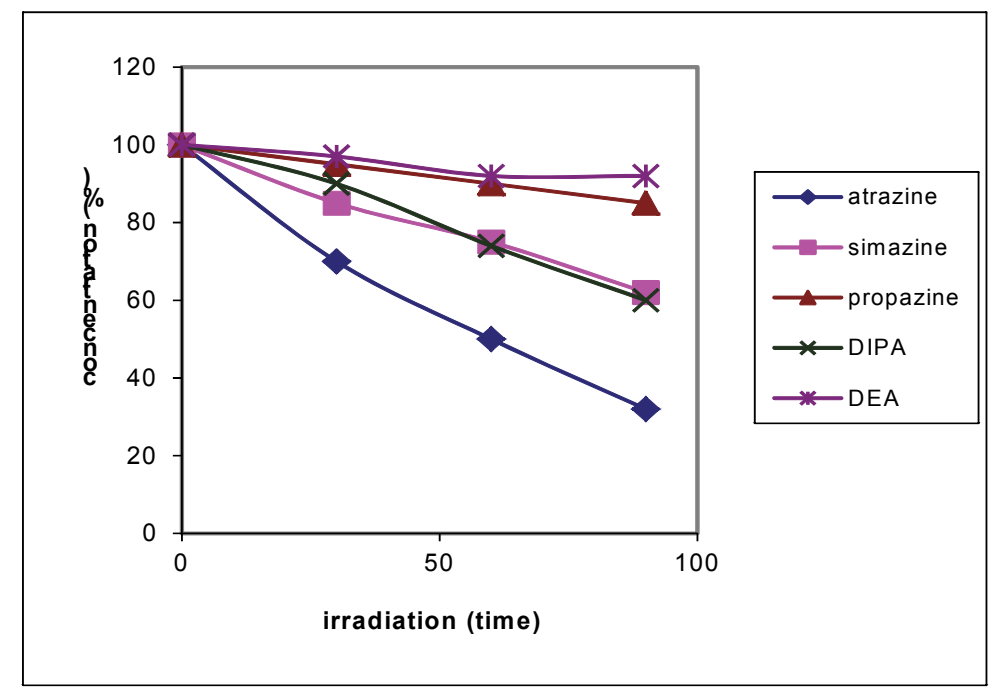

Fig. 8. Photosensitized degradation of triazine herbicides atrazine, simazine and propazine, and atrazine metabolites desethylatrazine (DEA) and desisopropylatrazine (DIPA) with anthraquinone sulfonate as the sensitizer. Initial concentration of individual substrates: $5.0^{*} 10^{-5} \mathrm{~mol} / \mathrm{l}$. Concentration of anthraquinonesulphonate after addition: $1^{*} 10^{-4} \mathrm{~mol} / \mathrm{l}$, addiotions each 30 minutes. Irradiation: Rayonet photochemical reactor RPR 100, lamps $3000 \AA ̊$, emission up to $290 \mathrm{~nm}$ filtered by optical glass. (From Klementová \& Hamsová, 2000).

$$
\mathrm{A} \rightarrow \mathrm{B}
$$

To achieve a photolytic decomposition highly energetic radiation is necessary. Usually a low pressure mercury lamp (emitting most radiation energy at the $254 \mathrm{~nm}$ wavelength) is used in these experiments. It is therefore obvious that such processes cannot contribute to herbicide degradation on the Earth's surface, but have their potential in waste-water and drinking water treatment. 
Photolytic degradation of triazine and phenylurea herbicides has been studied by several authors. Frimmel \& Hessler (1994) irradiated atrazine, desethyatrazine and simazine by low pressure mercury lamp. The rate constants of individual reaction were identical $\left(1.9^{*} 10^{-4} \mathrm{~s}^{-1}\right)$. Palm \& Zetzsch (1996) carried out kinetic experiments with atrazine, propazine and simazine irradiated by xenon lamp in quartz vessels. Their kinetic evalutation gave the rate constants similar to those calculated by Frimmel \& Hessler (1994); slightly higher rate constants and differing for the individual substrates studied were gained by Klementová \& Píšková (2005) who irradiated atrazine, simazine, propazine, desethylatrazine and desisopropylatrezine by RPR $3000 \AA ̊$ lamps (wavelength range 250 - $350 \mathrm{~nm}$ ) - see Table 3.

\begin{tabular}{|l|l|l|l|l|l|}
\hline triazine & atrazine & propazine & simazine & DEA & DIPA \\
\hline $\begin{array}{l}\text { rate } \\
\text { constant } \\
\left(\mathbf{s}^{-1}\right)\end{array}$ & $4.64^{*} 10^{-4}$ & $4.35^{*} 10^{-4}$ & $5.45^{\star} 10^{-4}$ & $5.86^{*} 10^{-4}$ & $6.33^{*} 10^{-4}$ \\
\hline
\end{tabular}

Table 3. First-order kinetics rate constant for photolytic UV degradation (lamps RPR 3000Å) of triazine and triazine derivatives. DEA - desethylatrazine; DIPA - desisopropylatrazine.

Phenylurea herbicides UV photolysis has been studied e.g. by Benitez et al. (2006) for chlorotoluron, diuron, isoproturon, and by Klementová \& Zemanová (2008) for chlorotoluron. Benitez et al. (2006) reported a dependence of the reaction rate on the $\mathrm{pH}$ value of the solution; the results published by Klementova \& Zemanová (2008) did not support the reported $\mathrm{pH}$ dependence, the degradation was $\mathrm{pH}$ independent in the range of $\mathrm{pH}$ values from 2 to 11 .

Measuring the content of dissolved organic carbon (DOC) by DOC analyzer revealed that photolysis in solutions saturated with air results in the partial mineralization of organic substrates, i.e. decomposition of the organic carbon into $\mathrm{CO}_{2}$. About $20 \%$ of organic carbon was mineralized in 90 minutes of irradiation.

Photolytic degradation by short-wavelength radiation therefore apparently represents a powerful tool for herbicides degradation in waste-water and drinking water treatment, since it leads to total decomposition of organic matter.

\subsection{Photochemical degradation of triazine and phenylurea herbicides - common features}

In all cases where photochemical degradation was observed in our experiments, the initial step of the degradation of the triazine and phenylurea herbicides and triazine herbicide metabolites was dechlorination and hydroxyderivative formation. Chlorine was found in the solution as chloride ions, $\mathrm{Cl}^{-}$, that were detected in the reaction mixtures by ion chromatography. Hydroxyderivatives were detected by high performance liquid chromatography with a mass spectrometer as an analyzer. Fig. 9 shows one example of herbicide (chlorotolurone) degradation, and chloride ions and hydroxyderivative formation. In this case, as well as in the case of other triazine substrates, the plots of the substrate decomposition and the chloride formation are perfectly symmetrical. Hydroxyderivatives are intermediates that decompose further with a reaction rate constant nearly equal to that of the original substrate decomposition. 


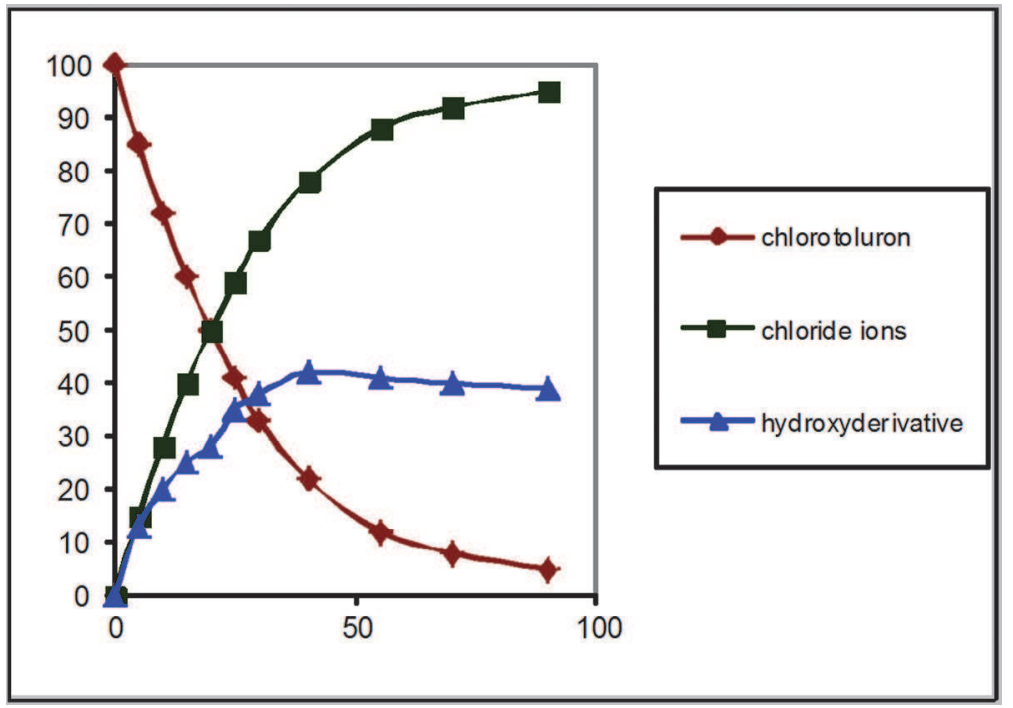

Fig. 9. Chloride ion release and hydroxyderivative formation in chlorotoluron photodecomposition.

\section{Conclusions}

In order to summarize the findings presented in this chapter on the photoinitiated degradation of triazine and phenylurea herbicides we can conclude:

- Direct sunlight photodegradation cannot proceed in natural surface waters since the substrates absorption maxima do not correspond to the solar action spectrum.

- In most cases natural (humic) sensitizers do not seem to have significant effects on degradation of the substrates. If the concentration of humic sensitizers is low, only a small amount of reactive oxidative species is formed and the degradation is ineffective. If the concentration of humic sensitizers is high, they absorb a lot of radiation themselves, thus radiation is reduced due to inner filtration and cannot reach molecules under the thin surface layer.

- Some artificial sensitizers cause herbicide degradation, but their application in wastewater and drinking water treatment cannot be expected; such sensitizers are expensive for other than small scale laboratory experiments and they themselves together with their degradation products would contaminate the water to which they were applied.

- Homogenous photocatalytic degradation seems to be able to contribute to photodegradation of the substrates in the natural water environment, the typical iron concentrations in natural waters are however not sufficient to bring about a significant conversion of the substrates.

- Heterogeneous photocatalysis with immobilised semiconductors and photolysis remain the only potentially helpful methods forthe removal of the recalcitrant herbicides from waste-waters and perhaps even from contaminated drinking waters. The obstacles connected with the use of these two approaches on a larger scale arise from the threedimensional nature of water purification: in assuring the delivery of sufficient amounts 
of light energy to enable purification of higher columns of solutions. With heterogenous photocatalysis the three-dimensionality has one more aspect: the photocatalytic reaction on a semiconductor is a surface process, thus the reactant must be captured by the photocatalyst surface.

- With all processess demanding artificial irradiation the cost of lamps and energy must be taken into consideration.

Nevertheless, environmental pollution including water and soil pollution with herbicides is an increasingly grave problem, and with herbicides resistent to biodegradation and persisting for a long time in the environment the possibilities of photochemical degradation will not cease to attract attention. The possibilities for further development are open especially in the area of heterogeneous photocatalysis. An important key to success will be the utilisation of nano-sized photocatalyst powders dispersed on substrates with extremely large surface areas. Another approach is the modification of $\mathrm{TiO}_{2}$ to make it sensitive to visible light. So far the researchers investigating in this field are struggling with the issue of low reproducibility and chemical stability, nonetheless heterogeneous photocatalysis represents a promising prospect for 21 century.

\section{Acknowledgement}

I would like to thank my son David Klement for his help with formulas and schemes drawing.

\section{References}

Amine-Khodja A., Trubetskaya O. Trubetskoj O., Cavani L., Ciavatta C., Guyot G. \& Richard C. (2006). Humic-like substances extracted from composts can promote the photodegradation of Irgarol 1051 in solar light. Chemosphere, Vol. 62, No. 6, pp. 1021 $-1027$.

Amorisco A., Losito I., Carbonara T., Palmisano F. \& Zamboni P.G. (2006). Photocatalytic degradation of phenyl-urea herbicides chlorotoluron and chloroxuron: Characterisation of the by-products by liquid chromatography coupled to electrospray ionization tandem mass spectrometry. Rapid Comm. Mass Spectrom., Vol. 20, pp. 1569 - 1576.

Badawi N., Rønhede S., Olsson S., Kragelund B. B., Johnsen A.H., Jacobsen O.S. \& Aamand J. (2009). Metalolites of phenylurea herbicides chlorotoluron, diuron, isoproturon and linuron produced by the soil fungus Mortierella sp. Environ. Poll., Vol. 157, No. 10, pp. $2806-2812$.

Behki R.M. \& Khan S.U. (1986). Degradation of Atrazine by Pseudomonas: N-dealkylation and dehalogenation of atrazine and its metabolites. J. Agric. Food Chem., Vol. 34, pp. $746-749$.

Behki R.M. \& Khan S.U. (1994). Degradation of atrazine, propazine and simazine by Rhodococcus Strain B-30. J. Agric. Food. Chem., Vol. 42, pp. 1237 - 1241.

Botta S.G., Navío J.A., Hidalgo M.C., Restrepo G.M \& Litter M.J. (1999). Photocatalytic properties of $\mathrm{ZrO}_{2}$ and $\mathrm{Fe} / \mathrm{ZrO}_{2}$ semiconductors prepared by a sol-gel technique. J. Photochem. Photobiol. A: CHem., Vol. 129, No 1 -2, pp. 89 - 99. 
Byrappa K., Subramani A.K., Ananda S., Lokanatha Rai K.M., Dinesh R. \& Yoshimura M. (2006). Photocatalytic degradation of rhodamine B dye using hydrothermally synthesized ZnO. Bull. Mater. Sci., Vol. 29, No. 5, pp. 433 - 438.

Comber S.D.W. (1999). Abiotic persistence of atrazine and simazine in water. Pestic. Sci., Vol. 55, pp. $696-702$.

Cooper W.J., Zika R.G., Petasne R.G. \& Fischer A.M. (1989). Sunlight-induced photochemistry in Humic substances in natural waters: Major reactive species. Aquatic humic substances: Influence on fate and treatment of pollutants. Eds.: Suffet J.H., Mac Carthy P. ACS Symposium Series 219, American Chemical Society, Washington D.C.

Crawford J.J., Traina S.J. \& Tuovinen O.H. (2000). Bacterial degradation of atrazine in redox potential gradients in fixed-film Sand columns. Soil Sci. Soc. Am. J., Vol.64, pp. 624 634.

Devilliers D. (2006). Semiconductor Photocatalysis: Still an Active Research Area Despite Barriers to Commercialization. Energia, CAER - University of Kentacky, Center for Applied Energy Research, Vol. 17., No. 3, pp. 1 - 3.

Dojlido J. \& Best G.A. (1993). Chemistry of water and water pollution. Ellis Horwood Limited, ISBN 0-13-878919-3, Chichester, England.

Dunliang Jian, Pu-Xian Gao, Wenjie Cai, Bamidele S. Allimi, Pamir Alpai S., Yong Ding, Zhong Lin Wang \& Brooks C. (2009). Synthesis, characterization, and photocatalytic properties of $\mathrm{ZnO} /(\mathrm{La}, \mathrm{Sr}) \mathrm{CoO}_{3}$ composite nanorod arrays. J. Mater. Chem., Vol. 19, pp. 970 - 975.

EPA Handbook (1998). Advanced Photochemical Oxidation Processes. EPA/625/R-98-004, Washington, DC.

Frimmel F.H. \& Hessler D.P. (1994). Photochemical degradation of triazine and anilide pesticides in natural waters. Aquatic and surface photochemistry. Eds. Helz G.R., Zepp R.G., Crosby D.G. CRC Press, Inc., Boca Raton, Florida.

Gerecke A.C., Canonica S., Müller S. R., Schärer M. \& Schwarzenbach R.P. (2001). Quantification of dissolved natural organic matter (DOM) mediated phototransformation of phenylurea herbicides in lakes. Environ. Sci. Technol., Vol. 35, No. 19, pp. 3915 - 3923.

Guo Y., Quan X., Lu N. Zhao H. \& Chen S. (2007). High photocatalytic capability of selfassembled nanoporous $\mathrm{WO}_{3}$ with preferential orientation of (002) planes. Environ. Sci. Technol., Vol. 41, No. 12, pp. 4422 - 4427.

Haque M.M., Muneer M. \& Bahnemann D.W. (2006). Semiconductor-mediated photocatalysed degradation of a herbicide derivative, chlorotoluron, in aqueous suspensions. Environ. Sci. Technol., Vol. 40, pp. 4765 - 4770.

Hashimoto K., Irie H. \& Fujishima A. (2005). $\mathrm{TiO}_{2}$ photocatalysis: A historical overview and future prospects. Jap. J. Appl. Physics, Vol. 44, No. 12, pp. 8269 - 8285.

Héquet V., Gonzalez C. \& Le Cloirec P. (2001). Photochemical processes for atrazine degradation: Methodological approach. Water Res., Vol. 35, No. 18, pp. 4253 - 4260.

Hoigné J., Faust B.C., Haag W.R., Scully F.E., Jr. \& Zepp R.G. (1989). Aquatic humic substances as sources and sinks of photochemically produced transient reactants. Aquatic humic substances: Influence on fate and treatment of pollutants. Eds.: Suffet J.H., Mac Carthy P. ACS Symposium Series 219, American Chemical Society, Washington D.C. 
Jason Krutz L., Shaner D.L.,Weaver M.A., Webb R.M., Zablotowicz R.M., Reddy K.N., Huang Y. \& Thomson S.J. (2010). Agronomic and environmental implication of enhanced s-triazine degradation. Pest. Manag. Sci., Vol. 66, No. 5, pp. 461 - 481.

Khadrani A., Seigle-Murandi F., Steiman R. \& Vroumsia T. (1999). Degradation of three phenylurea herbicides (chlorotoluron, isoproturon and diuron) by micromycetes isolated from soil. Chemosphere, Vol. 38, pp. $3041-3050$.

Klementová (2011). Photocatalytic degradation of triazine and phenylurea herbicides on $\mathrm{TiO}_{2}$. In preparation.

Klementova S. \& Hamsova K. (2000). Catalysis and sensitization in photochemical degradation of triazines. Res. J. Chem. Environ., Vol. 4, pp. 7 - 12.

Klementova S. \& Piskova V. (2005). UV photodegradation of triazine pesticides and their metabolites. Res. J. Chem. Environ., Vol. 9, pp. 20 - 23.

Klementová S. \& Zemanová M. (2008). UV Photochemical degradation of a phenyl-urea herbicide chlorotoluron. Res. J. Chem. Environ., Vol. 12, pp. 5 - 11.

Kodama T., Ding L., Yoshida M. \& Yajima M. (2001). Biodegradation of an s-triazine herbicide, simazine. J. Molecul. Catalysis B: Enzymatic, Vol. 11, 1073 - 1078.

Konstantinou I.K., Sakellarides T.M., Sakkas V.A \& Albanis. T.A. (2001a). Photocatalytic degradation of selected s-triazine herbicides and organophosphorus insecticides over aqueous $\mathrm{TiO}_{2}$ suspensions. Environ. Sci. Technol, Vol. 35, pp. 398 - 405.

Konstantinou I.K., Zarkadis A.K. \& Albanis T.A. (2001b). Photodegradation of selected herbicides in various natural waters and soils under environmental conditions. J. Environ. Qual., Vol. 30, pp. 121 - 130.

Lhomme L., Brosillon S., Wolbert D. \& Dussaud J. (2005). Photocatalytic degradation of a phenylurea, chlorotoluron, in water using an industrial titanium dioxide coated media. Appl. Catal. B: Environ., Vol. 61, pp. 227 - 235.

Lindner W., Rohermel J., Taschenbrecker E. \& Wohner G. (2000). Algicide combination. Patent No 6117817 (US).

Linsebigler A.L., Guangquan Lu \& Yates J.T., Jr. (1995). Photocatalysis on $\mathrm{TiO}_{2}$ Surfaces: Principles, mechanismsms, and selected results. Chem. Rev., Vol. 95, pp. 735 -758.

Mill T. (1989). Structure - activity relationship for photooxidation processes in the environment. Environ. Toxicology \& Chemistry, Vol. 8, No. 1. pp. 31 - 45.

Minero C., Pramauro E., Pelizzetti E., Dolci M. \& Marchesini A. (1992). Photosensitized transformation of atrazine under simulated sunlight in aqueous humic acid solution. Chemosphere, Vol. 24, No. 11, pp. 1597 - 1606.

Palm W.U. \& Zetzsch C. (1996). Investigation of the photochemistry and quantum yields of triazines using polychromatic irradiation and UV-spectroscopy as analytical tool. Intern. J. Environ. Anal. Chem., Vol. 65, pp. 313 - 329.

Pelizzetti E., Maurino V., Minero C., Carlin V., Praumaro E., Zebinatti O. \& Tosato M.L. (1990). Photocatalytic Degradation of Atrazine and other s- triazine herbicides. Environ. Sci. Technol., Vol. 24, pp. 1559 - 1565.

Penuela G. A. \& Barceló D. (2000). Comparative photodegradation study of atrazine and desethylatrazine in water samples containing titanium dioxide/hydrogen peroxide and ferric chloride/hydrogen peroxide. J. AOAC Int., Vol. 83, No. 1. pp. 53 - 60.

Schmitt P., Freitag D., Sanlaville Y., Lintelmann J. \& Kettrup A. (1995). Capillary electrophoretic study of atrazine photolysis. J. Chromatogr. A, Vol. 709, pp. 215 225. 
Schnitzer M. \& Khan S.U. (1972). Humic substances in the environment. Marcel Dekker, Inc., ISBN 0-8247-1614-0, New York.

Simmons M.S. \& Zepp R.G. (1986). Influence of humic substances on photolysis of nitroaromatic compounds in aqueous systems. Water Res., Vol. 20, No. 7, pp. 899 904.

Sørensen S.R., Bending G.D., Jacobsen C.S., Walker A. \& Aamand J. (2003). Microbioal degradation of isoproturon and related phenylurea herbicides in and below agricultural fields. VEMS Micobiol. Ecology, Vol. 45, pp. 1 - 11.

Tixier C., Bogaerts P., Sancelme M., Bonnemoy F., Twagilimana L. \& Cuer A. (2000a). Fungal biodegradation of a phenylurea herbicide, diuron: Structure and toxicity of metabolites. Pest. Manag. Sci., Vol. 56, pp. $455-462$.

Tixier C., Meunier L., Bonnemoy F. \& Boule P. (2000b). Phototransformation of three herbicides: chlorotoluron, isoproturon, and chlorotoluron: Influence of irradiation on toxicity. Int. J. Photoenergy, Vol. 2, pp. $1-8$.

Tixier C., Sancelme M., A ï t-A ï ssa S., Widehem P., Bonnemoy F. Cuer A., Trufaut N., \& Veschambre H. (2002). Biotransformation of phenylurea herbicides by a soil bacterial strain, Arthrocacter, sp. N2: Structure, ecotoxicity and fate of diuron metabolite with soil fungi. Chemosphere, Vol. 46, pp. 519 - 526.

Tixier C., Sancelme M., Bonnemoy F., Cuer A. \& Veschambre H. (2009). Degradation of a phenylurea herbicide, diuron: Synthesis, ecotoxicity, and biotransformation. Environ. Toxicol.Chem., Vol. 20, No. 7, pp. 1381 - 1389.

Tomlin C.D.S. (2003). The Pesticide Manual. BCPS (British Crop Protection Council), ISBN 1 90139613 4, Hampshire, UK.

Torstenson, L. (2001). Use of Herbicides on Railway Tracks in Sweden. Pest. Outlook., Vol.12, pp. $16-21$.

Wenk M., Baumgartner T., Dobovsek J., Fuchs T., Kucsera J., Zopfi J. \& Stucki G. (1998). Rapid atrazine mineralisation in soil slurry and moist soil by inoculation of an atrazine-degrading Pseudomonas sp. strain. Appl. Microbiol. Biotechnol, Vol. 49, pp. $624-630$.

Yongging Zha, Shaoyang Zhang \& Hui Pang (2007). Preparation, characterization and photocatalytic activity of $\mathrm{CeO}_{2}$ nanocrystalline using ammonium bicarbonate as precipitant. Material Letters, Vol. 61, No. 8 - 9, pp. 1863 - 1866. 


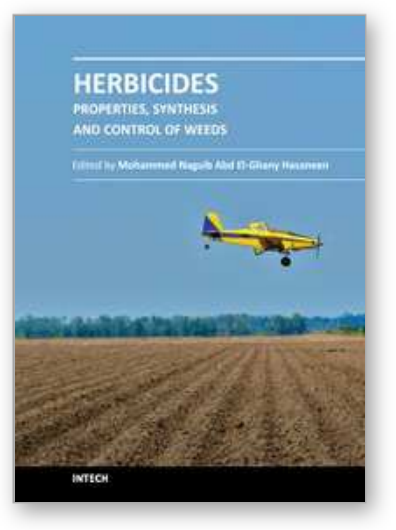

\author{
Herbicides - Properties, Synthesis and Control of Weeds \\ Edited by Dr. Mohammed Nagib Hasaneen
}

ISBN 978-953-307-803-8

Hard cover, 492 pages

Publisher InTech

Published online 13, January, 2012

Published in print edition January, 2012

This book is divided into two sections namely: synthesis and properties of herbicides and herbicidal control of weeds. Chapters 1 to 11 deal with the study of different synthetic pathways of certain herbicides and the physical and chemical properties of other synthesized herbicides. The other 14 chapters (12-25) discussed the different methods by which each herbicide controls specific weed population. The overall purpose of the book, is to show properties and characterization of herbicides, the physical and chemical properties of selected types of herbicides, and the influence of certain herbicides on soil physical and chemical properties on microflora. In addition, an evaluation of the degree of contamination of either soils and/or crops by herbicides is discussed alongside an investigation into the performance and photochemistry of herbicides and the fate of excess herbicides in soils and field crops.

\title{
How to reference
}

In order to correctly reference this scholarly work, feel free to copy and paste the following:

Sárka Klementova (2012). A Critical View of the Photoinitiated Degradation of Herbicides, Herbicides Properties, Synthesis and Control of Weeds, Dr. Mohammed Nagib Hasaneen (Ed.), ISBN: 978-953-307-8038, InTech, Available from: http://www.intechopen.com/books/herbicides-properties-synthesis-and-control-ofweeds/a-critical-view-of-the-photoinitiated-degradation-of-herbicides

\section{INTECH}

open science | open minds

\author{
InTech Europe \\ University Campus STeP Ri \\ Slavka Krautzeka 83/A \\ 51000 Rijeka, Croatia \\ Phone: +385 (51) 770447 \\ Fax: +385 (51) 686166 \\ www.intechopen.com
}

\author{
InTech China \\ Unit 405, Office Block, Hotel Equatorial Shanghai \\ No.65, Yan An Road (West), Shanghai, 200040, China \\ 中国上海市延安西路65号上海国际贵都大饭店办公楼 405 单元 \\ Phone: +86-21-62489820 \\ Fax: +86-21-62489821
}


(C) 2012 The Author(s). Licensee IntechOpen. This is an open access article distributed under the terms of the Creative Commons Attribution 3.0 License, which permits unrestricted use, distribution, and reproduction in any medium, provided the original work is properly cited. 